\title{
Corporate Social Responsibility Disclosure, Political Connection and Tax Aggressiveness: Evidence from China's Capital Markets
}

\author{
Xiaodan Chen \\ Management School, Jinan University, Guangzhou, China \\ Email:jnu_dannaschan@163.com
}

How to cite this paper: Chen, X.D. (2018) Corporate Social Responsibility Disclosure, Political Connection and Tax Aggressiveness: Evidence from China's Capital Markets. Open Journal of Business and Management, 6, 151-164.

https://doi.org/10.4236/ojbm.2018.61010

Received: December 25, 2017

Accepted: January 22, 2018

Published: January 25, 2018

Copyright $\odot 2018$ by author and Scientific Research Publishing Inc. This work is licensed under the Creative Commons Attribution International License (CC BY 4.0).

http://creativecommons.org/licenses/by/4.0/

\begin{abstract}
Corporate social responsibility disclosure, political connection and tax aggressiveness have become the focus of the media. By using samples of China's listed firms from 2008 to 2014, this study examines the relationship among corporate social responsibility disclosure, political connection and tax aggressiveness. The results show that corporate social responsibility disclosure significantly strengthens the possibility of tax aggressiveness; firms with no or less close political connections can make use of the disclosure of corporate social responsibility to do tax aggressiveness. Furthermore, the change of political connection can significantly weaken the positive association between corporate social responsibility disclosure and tax aggressiveness. However, some data are collected by hands and that may cause some deviations. These findings help governments, managements and investors evaluate firm's behavior and make decisions.
\end{abstract}

\section{Keywords}

Corporate Social Responsibility Disclosure, Political Connection, Tax Aggressiveness

\section{Introduction}

The problem of tax aggressiveness has always been a hot spot in the society and media at home and abroad. At home, on January 28, 2015, the State Administration of Taxation held a press conference and announced the tax violations in various parts of China in 2014 that had a total of 172.2 billion yuan of tax revenue of storage tax, an increase of $21.4 \%^{1}$. At abroad, on February 14, 2009 The Guardian pointed out that nearly $60 \%$ of corporate directors' considered taxa1http://www.cnnsr.com.cn/cssw/swhtml/20150522064852178094.html 
tion as an ethical issue. In October 2012, the Guardian pointed out that Starbucks had spent over $\mathfrak{£} 3$ billion in UK sales over the course of 14 years, but only had paid $£ 8.6$ million in corporate income tax. What's more, companies like Amazon, Google, Microsoft and Facebook had the same problems. As a result, The United Kingdom hoped to introduce the General Anti-Avoidance Rules (GAAR) in the 2013 fiscal act so as to strengthen tax collection and administration and combat tax abuse so as to avoid tax aggressiveness.

Tax aggressiveness and tax evasion are the focus of academic research. The empirical research around tax aggressiveness focuses on tax collection, corporate value and investment efficiency [1]. Tax aggressiveness is thought to adjust downward of taxable income through legal and possibly tax-deregulated activism [2] [3]. Tax aggressiveness will enable the government to impose inadequate tax revenue, which will have a negative impact on society. If the corporate has a behavior of tax aggressiveness, it will be considered unethical. However, the corporate has to pay "social costs" or "reputation costs" if it takes social responsibility, which in turn will cause shareholder dissatisfaction. Moreover, our country does not impose mandatory regulations on enterprises to disclose their social responsibilities, but only encourages them to voluntarily fulfill their social responsibilities and disclose information about the fulfillment of social responsibilities, including releasing sustainability reports and social responsibility reports. Disclosure of social responsibility information need to pay cost. Will it affect the corporate tax policy? Will it indirectly lead to corporate tax aggressiveness?

Existing research has proved that enterprises can get more resources and government subsidies by obtaining political connections, resulting in the actual tax rate in a lower level. In that way, will political connections affect the relationship between social responsibility information disclosure and tax aggressiveness? To this end, this paper uses CSRMAR database of listed companies in China's Shanghai and Shenzhen stock markets for 2008-2014 as a sample to study the relationship between the disclosure of social responsibility information and tax aggressiveness, political connections and its changes to impact the relationship between the disclosure of social responsibility information and tax aggressiveness. The paper is to answer the following questions: Is there any relationship between the disclosure of corporate social responsibility and the taxation radicalism? Will the political connection, the strength of political and changes of political connection affect the relationship between social responsibility information disclosure and tax aggressiveness?

Lanis and Richardson (2012) [4] find that social responsibility information disclosure is negatively correlated with effective tax rates; Hoi et al. (2013) [5] argue that companies with excessive non-social responsibility activities are more aggressive in tax avoidance. On the one hand, the conclusion of this paper can provide a theoretical basis for our tax administration to effectively supervise and restrict tax management problems of enterprise management. On the one hand, it can also help the government identify the beneficial or adverse effects of polit- 
ical connections on the relationship between the two and reduce the negative externalities, so as to provide investors with decision-making information.

\section{Literature Review and Hypothesis Development}

\subsection{Social Responsibility Disclosure and Tax Aggressiveness}

Corporation is considered as an entity, so it must develop a series of policies, strategies, and actions to grow to position itself well in a complex business environment or maximize shareholder wealth. According to agency theory, management considers the cost of corporate social responsibility as the cost of reputation or political costs when maximizing profits [2]. As a legal entity, corporate needs to take social responsibility even though it needs cost. Corporations are considered socially unacceptable if they tend to be tax-aggressive [4].

Risk management strategy theory believes that CSR activities can enhance its reputation for social responsibility to avoid risks of anti-political, regulatory and social sanctions [6]. Godfrey (2005) [7] argues that positive social reputation is important when there is a negative event in a business. This reputation helps to improve sanctions on the company's business, thus providing a degree of insurance coverage. Tax aggressiveness can lead to negative sanctions such as loss of corporate reputation, increased political pressure, penalty imposed by tax bureaus and even consumer boycotts [8]. Corporation will hedge the consequences of the negative sanctions by implementing a social responsibility strategy if reputation of social responsibility can reduce the radical tax-aggressive. In the meantime, Lanis and Richardson (2012) [4] find that the higher the degree of disclosure of corporate social responsibility, the lower the actual tax rate of enterprises by studying the degree of disclosure and the tax-aggressiveness of social responsibility in 408 listed companies in Australia in 2008-2009. Corporations disclosing social responsibility mislead people believe that they are responsible and will not be tax-aggressive. However, the financial fraudulent cases of Enron and WorldCom make us believe that many enterprises are carrying out taxation activism while carrying out social responsibility activities.

Corporate culture theory assumes that corporate social responsibility is the common philosophy of enterprises, and corporate tax payments have a positive impact on communities and society [9]. Companies that are tax-aggressive are widely viewed as unethical by the general public and mass media, and similarly as irresponsible corporate social responsibility [10]. Hoi et al. (2013) [5] argue that corporate social responsibility activities are closely linked to the interests of many stakeholders, while taxation has a radical impact on government demands on corporations and social welfare. They test the tax incentives in different ways and the results show that firms with four or more irresponsible CSR activities are more likely to be tax-aggressive and have higher accounting-tax differences. In order to promote a good corporate culture, management will convey the belief of social responsibility from the top to the bottom, objectively and truthfully record economic transactions from the bottom up, and will focus on avoiding down- 
ward tax revenue when conducting tax planning adjustment, reflecting the concept of corporate culture.

Disclosure of social responsibility information does not equate with social responsibility performance, but it can explain social responsibility performance. Disclosure of social responsibility information refers to the annual social responsibility report, environmental report, sustainability report and corporate citizen report disclosed by the enterprise each year, which contains other information such as social responsibility performance. Radical tax exposure makes the disclosure of social responsibility information is considered as "whitewashing" and reduces the credibility of the disclosure of social responsibility. Moreover, on the one way, the current tax system in our country is not perfect, and enterprises are vulnerable to the tax revenue radical tax loopholes. On the other way, corporate social responsibility information disclosure is a voluntary action; therefore, one of our focuses is on the link between tax aggressiveness and disclosure of social responsibility information. As such, the paper formulates the corresponding prediction from the risk-management perspective as follows:

H1: The more full disclosure of corporate social responsibility information, the higher level of the tax aggressiveness.

\subsection{Social Responsibility Disclosure, Political Connections and Tax Aggressiveness}

Many foreign studies show that having a political background in the management of a company brings policy preferences such as financing facilities and tax incentives to the enterprise, thereby increasing the enterprise value [11]. Adhikari et al. (2006) [11] study the relationship between the actual tax rate and political links based on a sample of 257 enterprises in Malaysia from 1990 to 1999 and find that there is a significant negative correlation between them which means that enterprises with political connections has significantly lower actual tax rates.

In China, seeking political ties may be beneficial to the economic development of itself and society. However, it may also hinder economic development because of rent-seeking [12]. $28.8 \%$ of private entrepreneurs think "the most important thing is to strive for being deputies and CPPCC members," and they show strong interest in political participation [13]. Weng Jianying (2015) [14] finds that the accounting earnings of private listed companies with political connections are significantly higher than that of private listed companies without political connections, which shows that political connections can increase the content of earnings information. Political identities can create tax avoidance effects, and taxpayers with political identities are more likely to become tax-aggressive [15].

Enterprises pay the cost of political connections as to look for political connections, but also receive the support of preferential tax policies. Corporates disclosing social responsibility information also need to pay a certain cost, but reap the rewards of social responsibility reputation. If companies get tax breaks when getting political connections, are they willing to pay social responsibility costs to 
take tax activism? As two voluntary mechanisms, will companies choose to pay a double cost to achieve the goal? This paper argues that enterprises with no political connection to get the government resources will tend to use the disclosure of social responsibility information to obscure tax aggressiveness. Therefore, this paper proposes the second research hypothesis:

H2: Relative to enterprises with political connection, enterprises with no political connection are more likely to be tax-aggressive by disclosing social responsibility information.

If management has served in local government departments or has local government resources, it is likely to receive more financial subsidies and more political support [16]. From the county, city, provincial and to even higher levels, enterprises increasingly pay more and more costs for their gradual search for political ties. This paper argues that companies with weaker political connections pay relatively lower costs, receive less government subsidies and receive less tax incentives will show red-eye to those who are stronger political connections. Therefore, they can only imply social responsibility activities to carry out radical taxation, with the expectation of obtaining the same tax consequences as those with strong political ties. For enterprises with strong political connections, the policy support and tax concessions they have obtained are in a favorable position to compete in the market so there is no need to spend a large amount of costs to conduct additional disclosure of social responsibility information and exacerbate the expenditure pressure on enterprises Therefore, this paper proposes the third research hypothesis:

H3: Relative to enterprises with strong political connections, enterprises with weaker political connections are more likely to be tax-aggressive by disclosing social responsibility information.

Changes in political relations will lead to greater uncertainty and increased management risks, so management will become more cautious. From no political connection to political connection, management will positively demonstrate "positive energy" and is likely to consciously reduce tax incentives, so as to establish long-term and stable political ties with the government. From political connections to political gaps, management may want to "wash the water" through disclosing of social responsibility information. Therefore, this paper proposes the forth research hypothesis:

H4: Political changes have weakened the relationship between the disclosure of social responsibility and tax aggressiveness.

\section{Research Design}

\subsection{Sample Selection and Data Sources}

Due to 2008 corporate tax reform and data availability, the paper chooses the A-share listed companies from 2008 to 2014 as the research sample, and rejects the corresponding data according to the following criteria: (1) Financial, insurance industry; (2) Financial data, corporate governance data missing; (3) New- 
ly listed companies; (4) The taxation level (the actual tax rate) is greater than 1 or less than 0 companies, and then get the final sample of 11,314 companies in the year. Financial data, governance structure data are from CSMAR, Wind database. Data of political connection is collected by hand which is from the resumes of corporate executives.

\subsection{Variable Definition}

Empirical studies show that the real tax rate reflects the tax-aggressive level of the firm [17], and academics often use the actual tax rate as an alternative tax revenue radical [18]. Therefore, The real tax rate (ETR) is the tax revenue level and is calculated using the effective tax rate = income tax expense/EBIT [3] [18] [19] [20]. The lower the tax rate, the higher the level of tax aggressiveness is.

The index method is widely used in the research of social responsibility information. In this paper, we refer to the classification of corporate social responsibility information disclosure index by Zhu Song et al. (2011) [21], Shen Hongtao (2007) [22], Lanis and Richardson (2012) [4] and the annual disclosure of listed companies by CSMAR database. The content of sample corporate social responsibility disclosure is divided into five categories: employees, suppliers, consumers, communities and the environment. At the same time for each type of information disclosure assignment, the disclosure is assigned a value of 1 , not assigned 0 , resulting in social responsibility information disclosure index, so the value ranges between 0 and 5 .

This paper draws on Hu Xuyang et al. (2008) [23] and Li Weian (2013) [15], defining political contact (PC) as chairman, general manager and chairman of the board of supervisors as former deputies or CPPCC members (county, city, province and nationwide). In H2, the Chairman, General Manager and Chairman of the Board of Supervisors served as the current NPC deputies or CPPCC members (county, city, province and nationwide) with a value of 1 , or 0 otherwise. In H3, the Political Link Strength (PCI) is measured using the exponential approach. The three methods for measuring the political connection index are as follows: the chairman, the general manager and the chairman of the board of supervisors are currently serving as officials at the rank of level above, NPC deputies and CPPCC members with an assignment of 3; Under the provincial level people's congress deputies, CPPCC members or served as officials at the level of above, NPC deputies or CPPCC members or provincial people's congress, CPPCC Standing Committee, the assignment is 2; served at the level of the following officials, provincial people's congress below CPPCC members Assignment is 1 ; no political background is assigned 0 . This gives the political link index, which ranges between 0 and 3. In H4, the change of political connection ( $\triangle$ PCI) adopts the assignment method. The change of the political ties between chairman, general manager and chairman of the supervisory board relative to the previous year has the value of 1 , and the change of 0 .

Other control variables are in Table 1. 
Table 1. Control variables and definitions.

\begin{tabular}{|c|c|c|c|}
\hline & \multicolumn{2}{|c|}{ Variable name and symbol } & \multirow{2}{*}{$\begin{array}{l}\text { Variable definitions } \\
\text { The natural logarithm of total assets at the end of a } \\
\text { business }\end{array}$} \\
\hline \multirow{13}{*}{$\begin{array}{l}\text { Control } \\
\text { Variable }\end{array}$} & Enterprise & Enterprise Size (SIZE) & \\
\hline & Feature & $\begin{array}{l}\text { Listing period } \\
\text { (AGEPUB) }\end{array}$ & Since the IPO business has been listed for years \\
\hline & & Leverage (LEV) & $\begin{array}{l}\text { Total liabilities at the end of the year divided by } \\
\text { total assets at the end of the year }\end{array}$ \\
\hline & $\begin{array}{c}\text { Assets } \\
\text { Structure }\end{array}$ & $\begin{array}{l}\text { Capital Intensity } \\
\quad \text { (CAPINT) }\end{array}$ & $\begin{array}{l}\text { Net fixed assets at the end of the year divided by } \\
\text { total assets at the end of the year }\end{array}$ \\
\hline & & $\begin{array}{l}\text { Inventory Intensity } \\
\text { (INVINT) }\end{array}$ & $\begin{array}{l}\text { Year-end inventories divided by total assets at the } \\
\text { end of the year }\end{array}$ \\
\hline & \multirow{2}{*}{$\begin{array}{c}\text { Profit } \\
\text { Capability }\end{array}$} & Return of Asset (ROA) & $\begin{array}{l}\text { Net profit divided by the average balance of total } \\
\text { assets }\end{array}$ \\
\hline & & $\begin{array}{l}\text { Investment Opportunity } \\
\qquad(\mathrm{MB})\end{array}$ & $\begin{array}{l}\text { Market book value ratio, year-end market value } \\
\text { divided by its book value }\end{array}$ \\
\hline & \multicolumn{2}{|c|}{ Ownership Concentration (TOP1) } & the largest shareholder's stake \\
\hline & \multicolumn{2}{|c|}{ Nominal Tax Rate (TAXRATE) } & The nominal tax rate for corporate income tax \\
\hline & \multicolumn{2}{|c|}{ Audit Opinion (OPINION) } & $\begin{array}{l}\text { Audit opinion for the year when the non-standard } \\
\text { audit report to take } 1 \text {, otherwise } 0\end{array}$ \\
\hline & \multicolumn{2}{|c|}{ Property (STATE) } & $\begin{array}{l}1 \text { when the enterprise belongs to state-owned } \\
\text { enterprises, otherwise } 0\end{array}$ \\
\hline & \multicolumn{2}{|c|}{ Annual Dummy Variable (YEAR) } & $\begin{array}{l}\text { Takes } 1 \text { when the variable data belongs to year } k, 0 \\
\text { otherwise }\end{array}$ \\
\hline & \multicolumn{2}{|c|}{ Industry Dummy Variable (INDUR) } & $\begin{array}{l}\text { Takes } 1 \text { when the firm belongs to industry } \mathrm{j}, 0 \\
\text { otherwise }\end{array}$ \\
\hline
\end{tabular}

In order to test $\mathrm{H} 1$ and $\mathrm{H} 2$, this paper constructs model (1).

$$
\begin{aligned}
\operatorname{LOG}\left(E R_{i t}\right)= & \beta_{0}+\beta_{1} \times S I_{i t}+\beta_{2} \times S D I_{i t} \times P C_{i t}+\beta_{3} \times \operatorname{SIZE}_{i t}+\beta_{4} \times L E V_{i t} \\
& +\beta_{5} \times \operatorname{CAPINT}_{i t}+\beta_{6} \times I N V I N T_{i t}+\beta_{7} \times R O A_{i t}+\beta_{8} \times T O P 1_{i t} \\
& +\beta_{9} \times M B_{i t}+\beta_{10} \times T_{A X R A T_{i t}}+\beta_{11} \times A G E P U B_{i t} \\
& +\beta_{12} \times O P I N I O N_{i t}+\beta_{13} \times \operatorname{STATE}_{i t}+\sum Y E A R+\sum I N D U R+\varepsilon_{i t}
\end{aligned}
$$

If the corporate social responsibility information is disclosed more fully, the actual tax rate is lower and then the higher level of tax aggressiveness then $\beta_{1}$ should be negative. Enterprises with no political connection are more likely to be tax-aggressive by disclosing social responsibility information, and then $\beta_{2}$ should be positive.

In order to test $\mathrm{H} 3$, this paper constructs model (2).

$$
\begin{aligned}
\operatorname{LOG}\left(\mathrm{ETR}_{i t}\right)= & \beta_{0}+\beta_{1} \times \operatorname{SDI}_{i t}+\beta_{2} \times \operatorname{SDI}_{i t} \times P C I_{i t}+\beta_{3} \times \operatorname{SIZE}_{i t}+\beta_{4} \times L E V_{i t} \\
& +\beta_{5} \times \mathrm{CAPINT}_{i t}+\beta_{6} \times I N V I N T_{i t}+\beta_{7} \times R O A_{i t}+\beta_{8} \times T O P 1_{i t} \\
& +\beta_{9} \times M B_{i t}+\beta_{10} \times T A X R A T_{i t}+\beta_{11} \times A G E P U B_{i t} \\
& +\beta_{12} \times O P I N I O N_{i t}+\beta_{13} \times S T A T E_{i t}+\sum Y E A R+\sum I N D U R+\varepsilon_{i t}
\end{aligned}
$$

If $\beta_{2}$ is positive, it indicates that enterprises with weaker political connections are more likely to be tax-aggressive by disclosing social responsibility information. 
In order to test $\mathrm{H} 4$, we build a model (3).

$$
\begin{aligned}
\operatorname{LOG}\left(\operatorname{ETR}_{i t}\right)= & \beta_{0}+\beta_{1} \times S D I_{i t}+\beta_{2} \times S D I_{i t} \times \Delta P C I_{i t}+\beta_{3} \times \operatorname{SIZE}_{i t}+\beta_{4} \times L E V_{i t} \\
& +\beta_{5} \times \operatorname{CAPINT}_{i t}+\beta_{6} \times I N V I N T_{i t}+\beta_{7} \times R O A_{i t}+\beta_{8} \times T O P 1_{i t} \\
& +\beta_{9} \times M B_{i t}+\beta_{10} \times T A X R A T_{i t}+\beta_{11} \times A G E P U B_{i t} \\
& +\beta_{12} \times O P I N I O N_{i t}+\beta_{13} \times \operatorname{STATE}_{i t}+\sum Y E A R+\sum I N D U R+\varepsilon_{i t}
\end{aligned}
$$

If $\beta_{2}$ is positive, it indicates that political changes have weakened the relationship between the disclosure of social responsibility and tax aggressiveness.

\section{Empirical Results Analysis}

\subsection{Descriptive Analysis of the Main Variables}

Table 2 reports descriptive statistics of all variables except year and industry control variables. The mean value of the effective tax (ETR) is 0.16 , with maximum and minimum of 0.99 and 0.000 respectively. This is because samples with the actual tax rate of less than 0 and greater than 1 are deleted. The average of the socially responsible disclosure index (SDI) is only 1.11 with the median 0 , indicating that most of the sample companies do not disclose social responsibility information, because China has not yet formulated related laws and regulations about the disclosure of social responsibility information and the capital market demand for such information is not strong. The average political connection (PC) was 0.23 with a median of 0 , indicating that most sample companies had no background for political connections. The change in political linkages $(\triangle \mathrm{PCI})$ averages 0.15 , suggesting that more than half of businesses with a background in political ties have undergone political transitions. The average SIZE is 21.90; the minimum is 20.09 and the maximum is 24.27 , indicating that most enterprises are close in size. LEV mean and median value are 0.45 and 0.46 ; the maximum and minimum values are 0.11 and 0.82 , indicating that the level of debt between enterprises is different, and there is a certain gap, but the overall condition of the financial structure of China's listed companies is good. The average capital intensity (CAPINT) is 0.23 , with the maximum and minimum values of 0.58 and 0.01 showing a large gap, indicating that the long-term investment gap between enterprises is large. INVINT has a mean of 0.17 , a median of 0.13 , a maximum and a minimum of 0.55 and 0.01 , a small mean and median, indicating that sample companies have less investment in inventory. In addition, the gap of the return on assets (ROA) is large; the minimum is negative; the maximum value of 0.14 . Equity concentration (TOP1) averages $36.33 \%$, with a median of $34.86 \%$, indicating that sample companies are more concentrated in equity. The mean of investment opportunities (MB) is 2.24 , with a median of 1.86 , indicating that $50 \%$ of sampled firms have lower expected value. The average age of listed companies (AGEPUB) is 9.27, with a median of 9, indicating that the general business listing is less than 10 years and the business operation may not be stable enough. The average of STATE is 0.48 , indicating that $48.2 \%$ of sample companies are stated-own companies. 
Table 2. Descriptive statistics.

\begin{tabular}{cccccc}
\hline Variables & Mean & Median & Min & Max & Standard deviation \\
\hline ETR & 0.16 & 0.15 & 0.000 & 0.998 & 0.10 \\
SDI & 1.11 & 0 & 0 & 5 & 2.00 \\
PC & 0.23 & 0 & 0 & 1 & 0.42 \\
PCI & 0.54 & 0 & 0 & 3 & 1.04 \\
$\triangle$ PCI & 0.15 & 0 & 0 & 1 & 0.33 \\
SIZE & 21.90 & 21.74 & 20.08 & 24.27 & 1.13 \\
LEV & 0.45 & 0.46 & 0.104 & 0.82 & 0.21 \\
CAPINT & 0.23 & 0.20 & 0.01 & 0.58 & 0.16 \\
INVINT & 0.17 & 0.13 & 0.01 & 0.54 & 0.14 \\
ROA & 0.05 & 0.04 & -0.05 & 0.14 & 0.04 \\
TOP1 (\%) & 36.25 & 34.71 & 13.93 & 63.54 & 14.44 \\
MB & 2.25 & 1.86 & 1.02 & 5.58 & 1.20 \\
AGEPUB & 9.27 & 9 & 1 & 24 & 5.91 \\
TAXRATE & 0.19 & 0.15 & 0.06 & 0.33 & 0.05 \\
OPINION & 0.02 & 0 & 0 & 1 & 0.14 \\
STATE & 0.48 & 0 & 0 & 1 & 0.50 \\
\hline
\end{tabular}

\subsection{Multiple Regression Analysis}

The Regression results are shown in Table 3 as belows. Model (1) regression shows that $\beta_{1}$ is negative and significantly correlated, confirming $\mathrm{H} 1$, that is, the more full disclosure of corporate social responsibility information, the higher level of the tax aggressiveness. It shows that the purpose of corporate social responsibility activities is not to serve the society. Maybe it is for the economic motivation and the disclosure of social responsibility information may be the "facade decoration", hoping to enhance the corporate reputation which can provide certainty to the enterprise of the security and to buffer the impact of its negative events. $\beta_{2}$ is positive and it is significantly related to the actual tax rate, indicating that relative to enterprises with political connection, enterprises with no political connection are more likely to be tax-aggressive by disclosing social responsibility information, in line with the expectation of the second assumption. Companies with weaker political connections pay relatively lower costs, receive less government subsidies and receive less tax incentives will show red-eye to those who are stronger political connections. For the politically connected enterprises, the policy support and tax concessions they have obtained are in a favorable position to compete in the market. Therefore, there is no need to spend a large amount of additional information on social responsibility disclosure to exacerbate the expenditure pressure on enterprises.

$\beta_{2}$ is positive and significant correlations in model (2), indicating that relative to enterprises with strong political connections, enterprises with weaker 
Table 3. The regression results.

\begin{tabular}{|c|c|c|c|}
\hline \multirow{2}{*}{ Variables } & \multicolumn{3}{|c|}{ Estimated Coefficient } \\
\hline & Model (1) & Model (2) & Model (3) \\
\hline Constant & $-4.41^{* * *}$ & $-4.40^{\star * *}$ & $-4.43^{* * *}$ \\
\hline SDI & $-0.011^{\star \star}$ & $-0.011^{\star \star}$ & $-0.008^{*}$ \\
\hline $\mathrm{SDI} \times \mathrm{PC}$ & $0.018^{\star *}$ & & \\
\hline $\mathrm{SDI} \times \mathrm{PCI}$ & & $0.007^{\star *}$ & \\
\hline $\mathrm{SDI} \times \triangle \mathrm{PCI}$ & & & $0.019^{*}$ \\
\hline SIZE & $0.070^{* * *}$ & $0.0696^{\star * *}$ & $0.071^{\star * *}$ \\
\hline LEV & $-1.04^{\star * *}$ & $-1.04^{\star * *}$ & $-1.04^{* * *}$ \\
\hline CAPINT & $-0.76^{\star * *}$ & $-0.76^{\star * *}$ & $-0.76^{* * *}$ \\
\hline INVINT & $0.72^{\star * *}$ & $0.72^{\star * *}$ & $0.72^{* * *}$ \\
\hline ROA & $1.88^{\star * *}$ & $1.88^{\star * *}$ & $1.88^{* * *}$ \\
\hline TOP1 & $0.002^{* * *}$ & $0.002^{* * *}$ & $0.002^{* * *}$ \\
\hline MB & $-0.058^{* * *}$ & $-0.058^{\star * \star}$ & $-0.057^{\star * *}$ \\
\hline AGEPUB & $-0.006^{\star * *}$ & $-0.006^{\star * *}$ & $-0.006^{* * *}$ \\
\hline TAXRATE & $2.07^{\star * *}$ & $2.07^{\star * *}$ & $2.07^{* * *}$ \\
\hline OPINION & $-0.45^{\star * *}$ & $-0.45^{\star * \star}$ & $-0.45^{\star * *}$ \\
\hline STATE & -0.16 & -0.16 & -0.19 \\
\hline YEAR & & Control & \\
\hline INDUR & & Control & \\
\hline Adjust R2 & 0.1319 & 0.1319 & 0.1318 \\
\hline $\mathrm{F}$ & $58.27^{* * *}$ & $58.31^{* * *}$ & $58.23^{* * *}$ \\
\hline $\mathrm{N}$ & 11314 & 11314 & 11314 \\
\hline
\end{tabular}

Note: ${ }^{* *}$ indicates significant at $1 \%$ level (bilateral); ${ }^{*}$ indicates significant at $5 \%$ level (bilateral); ${ }^{*}$ indicates significant at $10 \%$ level (bilateral).

political connections are more likely to be tax-aggressive by disclosing social responsibility information, in line with $\mathrm{H} 3$ expectation. Enterprises with higher political connection have paid a high cost to obtain the corresponding policy support and taxation resources. In contrast, the enterprises with weak political connections have relatively lower cost but gain less policy support and tax preference will have "red-eye" towards companies' additional resources.

$\beta_{2}$ is positive and significant correlations in model (3), which confirms that the changes in political connections in $\mathrm{H} 3$ cause the enterprises to face greater uncertainty. From the political gap to the political connection, management will actively demonstrate "positive energy". From political connection to political gap, management may wish to "cleanse" by disclosing social responsibility information while companies with stable political ties tend to mask tax incentives by disclosing social responsibility information. 


\subsection{Robustness Test}

In order to explain the relationship between social responsibility information disclosure and the level of tax aggressiveness, this paper uses Book-Tax Difference (BTD) and Corporate Social Responsibility (CSR) as the alternative variables of explanatory variables and explanatory variables respectively.

Chen et al. (2010) [2] find that BTD is applicable in China as a measure of tax avoidance. Using Desai's (2006) [24] approach, BTD = (total profit - current income tax expense/nominal tax rate)/total assets, the greater the BTD difference, the higher level of tax aggressiveness. The results are shown in Table 4 below. It shows that the more full disclosure of corporate social responsibility information, the higher level of the tax aggressiveness. Relative to enterprises with political connection, enterprises with no political connection are more likely to be tax-aggressive by disclosing social responsibility information. Relative to enterprises with strong political connections, enterprises with weaker political connections are more likely to be tax-aggressive by disclosing social responsibility information. Political changes have weakened the relationship between the disclosure of social responsibility and tax aggressiveness.

In addition, the index of social responsibility information disclosure is reassigned, that is, if the enterprise has disclosed social responsibility information, the value of 1 is assigned; otherwise, the value is 0 . The results in Table 5 below indicate that the more full disclosure of corporate social responsibility information, the higher level of the tax aggressiveness. Relative to enterprises with political connection, enterprises with no political connection are more likely to be tax-aggressive by disclosing social responsibility information. Relative to enterprises with strong political connections, enterprises with weaker political connections are more likely to be tax-aggressive by disclosing social responsibility information. Political changes have weakened the relationship between the disclosure of social responsibility and tax aggressiveness.

Table 4. The regression results of BTD.

\begin{tabular}{cccc}
\hline Variables & \multicolumn{3}{c}{ Estimated Coefficient } \\
\cline { 2 - 4 } & Model $(1)$ & Model $(2)$ & Model $(3)$ \\
\hline Constant & $-2.79^{* * *}$ & $-2.81^{* * *}$ & $-2.76^{* * *}$ \\
SDI & $0.02^{* * *}$ & $0.02^{* * *}$ & 0.01 \\
SDI $\times$ PC & $-0.03^{* * *}$ & & \\
SDI $\times$ PCI & & $0.01^{* * *}$ & 0.00 \\
SDI $\times \triangle$ PCI & & & $-0.08^{* * *}$ \\
STATE & $-0.08^{* * *}$ & $-0.08^{* * *}$ & 0.1082 \\
Adjust R2 & 0.1088 & 0.1090 & $52.24^{* * *}$ \\
F & $52.55^{* * *}$ & $52.65^{* * *}$ &
\end{tabular}

Note: ${ }^{* * *}$ indicates significant at $1 \%$ level (bilateral); ${ }^{* *}$ indicates significant at $5 \%$ level (bilateral); ${ }^{*}$ indicates significant at $10 \%$ level (bilateral). 
Table 5. The regression results of CSR.

\begin{tabular}{|c|c|c|c|}
\hline \multirow{2}{*}{ Variables } & \multicolumn{3}{|c|}{ Estimated Coefficient } \\
\hline & Model (1) & Model (2) & Model (3) \\
\hline Constant & $-4.40^{\star * *}$ & $-4.41^{\star * *}$ & $-4.43^{\star * *}$ \\
\hline SDI & $-0.05^{\star}$ & $-0.05^{\star}$ & -0.04 \\
\hline $\mathrm{SDI} \times \mathrm{PC}$ & $0.03^{* *}$ & & \\
\hline $\mathrm{SDI} \times \mathrm{PCI}$ & & $0.8^{*}$ & \\
\hline $\mathrm{SDI} \times \triangle \mathrm{PCI}$ & & & $0.08^{*}$ \\
\hline STATE & -0.02 & -0.02 & -0.02 \\
\hline Adjust R2 & 0.1342 & 0.1341 & 0.1340 \\
\hline $\mathrm{F}$ & $58.28^{\star * *}$ & $58.24^{* * *}$ & $58.21^{\star * *}$ \\
\hline
\end{tabular}

Note: ${ }^{* *}$ indicates significant at $1 \%$ level (bilateral); ${ }^{*}$ indicates significant at $5 \%$ level (bilateral); ${ }^{*}$ indicates significant at $10 \%$ level (bilateral).

\section{Conclusion}

The empirical test of the data of listed companies in A-share of Shanghai and Shenzhen stock exchanges in China from 2008 to 2014 shows that there is a positive correlation between the level of the disclosure of corporate social responsibility information and the level of the tax aggressiveness; enterprises with no political connection are more likely to be tax-aggressive by disclosing social responsibility information; enterprises with strong political connections, enterprises with weaker political connections are more likely to be tax-aggressive by disclosing social responsibility information; political changes have weakened the relationship between the disclosure of social responsibility and tax aggressiveness. It can be indicated that the corporate social responsibility activities are not based on the fact that the enterprises serve the society sincerely, but are economically motivated-they may mask the tax aggressiveness by disclosing the social responsibility information, and the reputation of social responsibility can weaken the consequences of tax aggressiveness. Enterprises with no political connection or with weak political connections have to resort to tax aggressiveness through social responsibility activities without obtaining additional resources in order to achieve the same tax consequences as enterprises with strong political ties. Changes in political connections will prompt management to be cautious about tax incentives. The conclusion of the study has some practical significance. It not only expands the academic research on the impact of the disclosure of social responsibility information on the tax aggressiveness, but also provides a theoretical basis for the effective supervision and restriction of the taxation of the enterprise management by China's Inland Revenue Department, preventing enterprises from using the disclosure of responsibility information to take tax aggressiveness. However, as it is hard to get tax returns from corporates and some data are collected by hands, the paper also has some limitations and subsequent research can be improved on the basis of these points. 


\section{References}

[1] Hanlon, M. and Heitzman, S. (2010) A Review of Tax Research. Journal of Accounting and Economics, 2-3, 127-178.

https://doi.org/10.1016/j.jacceco.2010.09.002

[2] Chen, S., Chen, X. and Cheng, Q. (2010) Are Family Firms More Tax Aggressive than Non-Family Firms? Journal of Financial Economics, 95, 41-61.

https://doi.org/10.1016/j.jfineco.2009.02.003

[3] Lanis, R. and Richardson, G. (2011) The Effect of Board of Director Composition on Corporate Tax Aggressiveness. Journal of Accounting and Public Policy, 30, 50-70. https://doi.org/10.1016/j.jaccpubpol.2010.09.003

[4] Lanis, R. and Richardson, G. (2012) Corporate Social Responsibility and Tax Aggressiveness: An Empirical Analysis. Journal of Accounting and Public Policy, 31, 86-108. https://doi.org/10.1016/j.jaccpubpol.2011.10.006

[5] Hoi, C.H., Wu, Q. and Zhang, H. (2013) Is Corporate Social Responsibility (CSR) Associated with Tax Avoidance? Evidence from Irresponsible CSR Activity. Accounting Review, 88, 2025-2059. https://doi.org/10.2308/accr-50544

[6] Godfrey, P.C., Merrill, C.B. and Hansen, J.M. (2009) The Relationship between Corporate Social Responsibility and Shareholder Value: An Empirical Test of the Risk Management Hypothesis. Strategic Management Journal, 30, 425-445. https://doi.org/10.1002/smj.750

[7] Godfrey, P.C. (2005) The Relationship between Corporate Philanthropy and Shareholder Wealth: A Risk Management Perspective. Academy of Management Review, 30, 777-798. https://doi.org/10.5465/AMR.2005.18378878

[8] Hanlon, M. and Slemrod, J. (2009) What Does Tax Aggressiveness Signal? Evidence from Stock Price Reactions to News about Tax Shelter Involvement. Journal of Public Economics, 93, 126-141. https://doi.org/10.1016/j.jpubeco.2008.09.004

[9] Freedman, J. (2003) Tax and Corporate Responsibility. Tax Journal, 695, 1-4.

[10] Weisbach, D.A. (2002) An Economic Analysis of Anti-Tax-Avoidance Doctrines. American Law and Economics Reviews, 1, 88-115.

https://doi.org/10.1093/aler/4.1.88

[11] Adhikari, A., Derashid, C. and Zhang, H. (2006) Public Policy, Political Connections, and Effective Tax Rates: Longitudinal Evidence from Malaysia. Journal of Accounting and Public Policy, 25, 574-595. https://doi.org/10.1016/j.jaccpubpol.2006.07.001

[12] Yu, M.G., Hui, Y.F. and Pan, H.B. (2010) Political Connections, Rent Seeking, and the Fiscal Subsidy Efficiency of Local Governments. Journal of Economic Study, 3, 65-77.

[13] Deng, J.P. and Zeng, Y. (2009) Can Political Connection Improve the Performance of Private Enterprises. China Industrial Economics, 2, 98-108.

[14] Weng, J.Y. (2015) Political Connections and the Earnings Response Coefficient: Evidence from Chinses Private Listed Firms. Journal of Accounting and Economics, 2, 60-77.

[15] Li, W.A. and Xu, Y.K. (2013) Political Identity Effects Tax Avoidance. Journal of Financial Research, 3, 114-129.

[16] Wu, W.F., Wu, C.F. and Liu, X.W. (2008) Political Connection and Market Valuation: Evidence from China Individual-Controlled Listed Firms. Journal of Economics, 7, 130-141. 
[17] Robinson, J.R., Sikes, S.A. and Weaver, C. (2010) Performance Measurement of Corporate Tax Departments. The Accounting Review, 85, 1035-1064. https://doi.org/10.2308/accr.2010.85.3.1035

[18] Dyreng, S.D., Hanlon, M. and Maydew, E.L. (2008) Long-Run Corporate Tax Avoidance. The Accounting Review, 83, 61-82. https://doi.org/10.2308/accr.2008.83.1.61

[19] Richardson, G. and Lanis, R. (2007) Determinants of the Variability in Corporate Effective Tax Rates and Tax Reform: Evidence from Australia. Journal of Accounting and Public Policy, 26, 689-704. https://doi.org/10.1016/j.jaccpubpol.2007.10.003

[20] Wu, L.S. (2009) State Ownership, Preferential Tax, and Corporate Tax Burdens. Journal of Economics, 10, 109-120.

[21] Zhu, S. (2011) Corporate Social Responsibility, Market Evaluation and Informativeness of Accounting Earnings. Accounting Review, 11, 27-34.

[22] Shen, H.T. (2007) Corporate Characteristics and Social Disclosure-Evidence from Listed Companies in China. Accounting Review, 3, 9-17.

[23] Hu, X.Y. and Shi, J.C. (2008) Political Resource and Diversification of Chinese Private Enterprises-Evidence from the Largest 500 Private Enterprises. China Industrial Economics, 4, 5-14.

[24] Desai, M.A. and Dharmapala, D. (2006) Corporate Tax Avoidance and High-Powered Incentives. Journal of Financial Economics, 79, 145-179.

https://doi.org/10.1016/j.jfineco.2005.02.002 